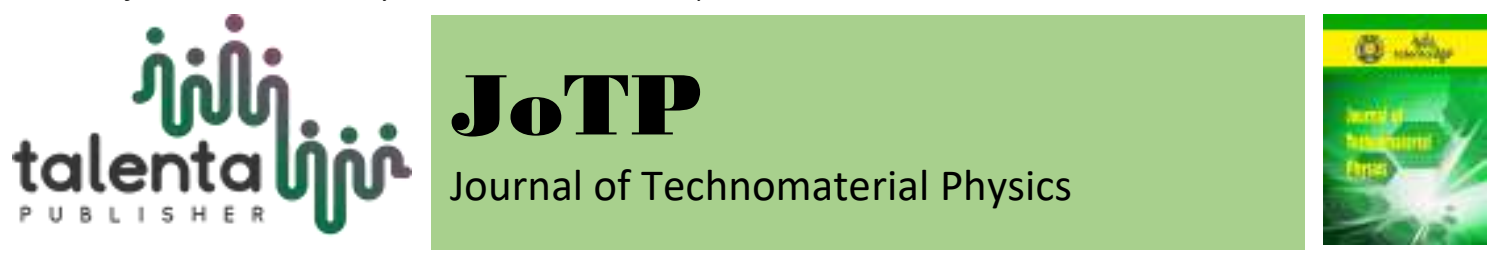

\title{
The Fabrication and Characterizations of Coal Briquettes Composed by Charcoal - Clay - Rice Husk Ashes and Adhesive
}

\author{
Manis Sembiring ${ }^{1}$ \\ ${ }^{1}$ Department of Physics, Faculty of Mathematics and Natural Science, Universitas Sumatera Utara \\ 20155, Indonesia
}

\begin{abstract}
Coal briquettes are solid materials that can be used as fuels. The composition of this solid fuels are mixed by clay as the ashes binder, rice husks powder as flame additives, and starch flour as adhesive materials. These materials were prepared in different ratio to be mixed homogeneously which are determined accordingly. The fabrication was conducted by mixing methods, and pressed by hydraulic press within $3100 \mathrm{KPa}$. The results were placed inside an oven to be dried for 24 hours within $85^{\circ} \mathrm{C}$ of temperature, followed by 24 hours of allowing standing in room temperature. Afterward, the characterizations of the coal briquettes were done by performing density and compressive strength, while the others physical properties such as specific heat, combustion, and purity properties were also tested. The physical properties showed that coal briquettes are flammable and high ignition characteristics. The stability and speed of combustion to fire have continuous and fixed combustion indicated by the presence of solid ashes. The samples suggested that the $\mathbf{M}_{1}$ samples provided fragile ashes with mass loss accounted for $56.33 \%$, and it has the highest specific heat values accounted for $246.66 \mathrm{Kcal} / \mathrm{Kg}$. Meanwhile, the lowest specific heat value was $162.26 \mathrm{Kcal} / \mathrm{Kg}$ which was M4 samples with mass loss for $34.53 \%$.
\end{abstract}

Keyword: Briquettes, clays, rice husks ashes, coal

Received 01 Mei 2019|Revised [25 August 2019] | Accepted [31 August 2019]

\section{Introduction}

Coal briquettes are solid fuels composed by charcoal added by additive and adhesive materials [1-3]. The briquettes are considered as an alternative source in replacing the main energy resources to replace the fossil fuels. The amounts of petroleum and charcoal are originated from solid and liquid carbon substances [4-7].

The main objective of fabricating the coal briquettes is to provide solid fuels from charcoal with better composition, so that this material is operable and applicable to be utilized compared to the use of charcoal in direct combustion [8]. To obtain good coal briquettes which have low percentage of sulfur and ashes, a good adhesive material accelerates the combustion point as

\footnotetext{
*Corresponding author at: Jl. Bioteknologi No.1 Kampus USU, Medan, Indonesia, 20155

E-mail address: manis@usu.ac.id
} 
well as absorbing the hazard emissions and substances [9-10]. There are several reasons about the use of charcoal to be planned as a potential substitution for petroleum due to the affordability, while the thermal characteristics suggest high and continuous specific heat value. Subsequently, the combustion process occurs without noise, non-soot fractions, vast sources, and the amounts of residual combustion are not scattered. One of the optimum types of charcoal are carbonized coals which are categorized as a super material. This type of coal has been carbonized before being mixed into a briquette, so that this coal produces less odor, and smoke. However, to produce these coal briquettes, the cost of production is relatively high due to the process of uncommon carbonization. On the other hand, a coal briquette which is produced with common carbonization has unstable substances, so that the characteristics are lower compared to those from uncommon carbonization because of the presence certain matters. Therefore, the use of common-carbonized coal briquettes are commonly used small-scale industries [8]. To produce feasible coal briquettes as proper fuels, the charcoal requires to be composed with additives, such as ignition materials (rice husks), adhesives (starch powder), and bonded materials (clay) [11-14].

The selection of rice husks is based on the carbonic composition which can be easily combusted, while the starch powder has adhesive properties with $47 \%$ of selenium oxide, $39 \%$ of aluminum oxide, and $14 \%$ of water [15-17]. Density is the mass ratio to volume of a matter. The briquettes density characteristic is determined by the following equations:

$$
\rho=\frac{m}{v}
$$

where $\mathrm{m}$ is mass $(\mathrm{g}), \mathrm{v}$ is volume $\left(\mathrm{cm}^{3}\right)$ and $\rho$ is density $\left(\mathrm{gram} / \mathrm{cm}^{3}\right)$.

The compressive strength characteristic is the maximum value of samples resistance to the impact given to the samples, calculated mathematically by the following equations:

$$
P=\frac{F}{A}
$$

where $\mathrm{F}$ is force $(\mathrm{lbm}), \mathrm{A}$ is surface area of the briquettes $\left(\mathrm{cm}^{2}\right)$ and $\mathrm{P}$ is pressure $\left(\mathrm{lbm} / \mathrm{cm}^{2}\right)$.

In fabrication a briquette, this material is expected to be ignited feasibly. Subsequently, the additives affects the ignition times, which in this case is rice husks ashes. To investigate the residual materials formed after combustion, the test is conducted. The missing of clay is expected to result constant residual combustion of briquettes. In testing the residual ashes, mass loss calculation was determined by observing the pores formed on the ashes from the briquettes combustions. The following equation illustrates mass loss [4].

$$
M_{H}=\frac{\Delta m}{m_{0}} x 100 \% \text { or } M_{H} \frac{\left(m_{0}-m_{t}\right)}{m_{0}} \times 100 \%
$$

where $\mathrm{m}_{0}$ is initial mass, $\mathrm{m}_{\mathrm{t}}$ is final mass and $\mathrm{M}_{\mathrm{H}}$ is loss mass (\%). 


\section{Materials and Methods}

The tools used in this study are digital analytical balance, oven, spatula, hydraulic pumps, beaker glasses, porcelain bowl, and 100 meshes of sieve, calipers, thermometer, and UTM. The materials are the amounts of charcoal and rice husks powders, ceramic clays, and starch as adhesive materials.

The preparation of materials is begun by fining the charcoals which were filtered by 100 mesh of sieve. Then, the samples were dried within $85^{\circ} \mathrm{C}$ for 24 hours to remove the water content, while at the same time the amounts of rice husks were prepared as well as the charcoals did. Meanwhile, the amounts of starch powders were mixed with $20 \mathrm{ml}$ of water, and these amounts were heated in constant stirring to form adhesive materials. Finally all the materials prepared were mixed and stirred constantly to reach homogeneous state, and this mixed material was placed on the hydraulic press to be pressed in $3100 \mathrm{KPa}$ for 20 units of briquettes.

\section{Result and Discussion}

\subsection{Density}

The density property of the charcoal was determined by the equation 1 . The following Table 1 illustrates the density of the samples prepared.

Table 1. Density samples

\begin{tabular}{cccc}
\hline Samples & Mass $(\mathrm{g})$ & Clay density $\left(\mathrm{g} / \mathrm{cm}^{3}\right)$ & Charcoal density $\left(\mathrm{g} / \mathrm{cm}^{3}\right)$ \\
\hline $\mathrm{M}_{1}$ & 40 & 1.16 & 1.79 \\
$\mathrm{M}_{2}$ & 60 & 1.41 & 1.57 \\
$\mathrm{M}_{3}$ & 100 & 1.57 & 1.41 \\
$\mathrm{M}_{4}$ & 120 & 1.79 & 1.16 \\
\hline
\end{tabular}

According to Table 1, the line graphs that have relationship between the densities and charcoal mass are displayed by the following Figure $1 \mathrm{a}$ and $1 \mathrm{~b}$.
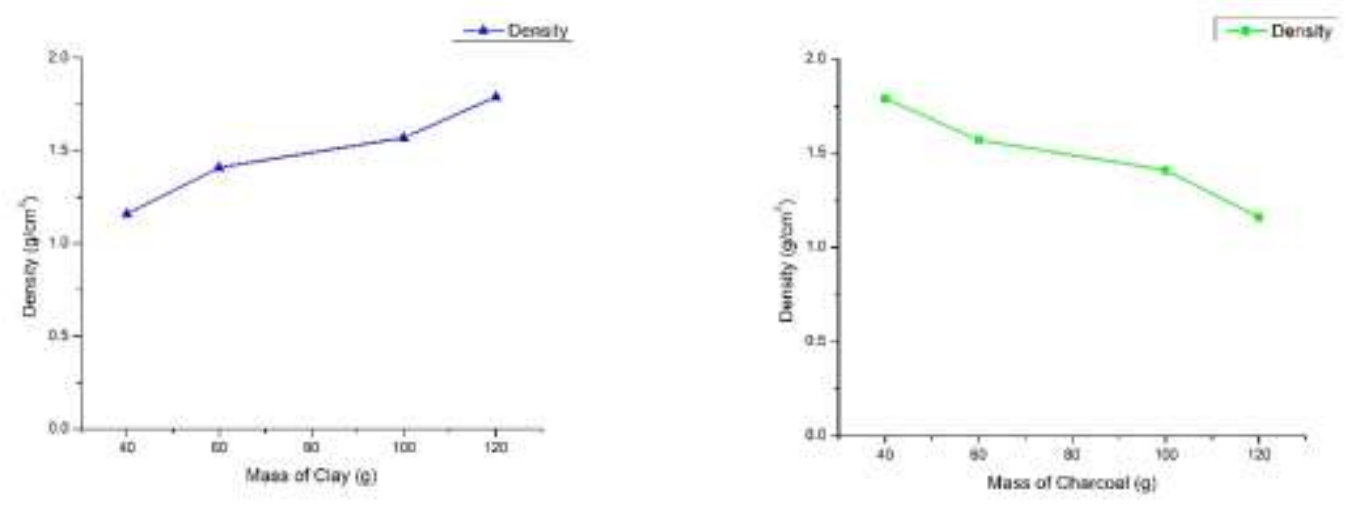

Figure 1. The line graph of density and mass of (a) Clay and (b) Charcoal 
From the Figure 1a, it can be seen that the density value tends to increase as well as the inclining clay mass. This showed the amounts of clay are more solid than the charcoal. The linearity equations in the line graph suggested that the clay briquettes already had $0.8 \mathrm{gr} / \mathrm{cm}^{3}$ before being added by the others additive materials.

The charcoal mass of the briquettes composition also affects the density samples as it is displayed by Figure $1 \mathrm{~b}$. From the figure $1 \mathrm{~b}$ above, the increase of charcoal composed within the samples provided lower density value, as well as it is vice versa. This is affected because of the drying process time inside the heater, so that the material compositions stressed due to the presence of charcoal within the charcoal briquettes.

\subsection{Compressive Strength}

To obtain a good quality of compressive strength of briquettes, the pressing molding step done by hydraulic pumps must be conducted in constant pressure, i.e. $3100 \mathrm{KPa}$. The compressive strength is calculated by the equation 2 , and the results could be observed by the following Table 2 below:

Table 2. Compressive strength of every sample

\begin{tabular}{cccc}
\hline Samples & Clay mass $(\mathrm{g})$ & Charcoal mass $(\mathrm{g})$ & Compressive Strength $\left(\mathrm{g} / \mathrm{cm}^{2}\right)$ \\
\hline $\mathrm{M}_{1}$ & 40 & 120 & 56.10 \\
$\mathrm{M}_{2}$ & 60 & 100 & 64.65 \\
$\mathrm{M}_{3}$ & 100 & 60 & 72.82 \\
$\mathrm{M}_{4}$ & 120 & 40 & 86.65 \\
\hline
\end{tabular}

From the Table 2, the line graph could be set up by forming the relationship between mass and compressive strength (Figure 2a, and Figure 2b).
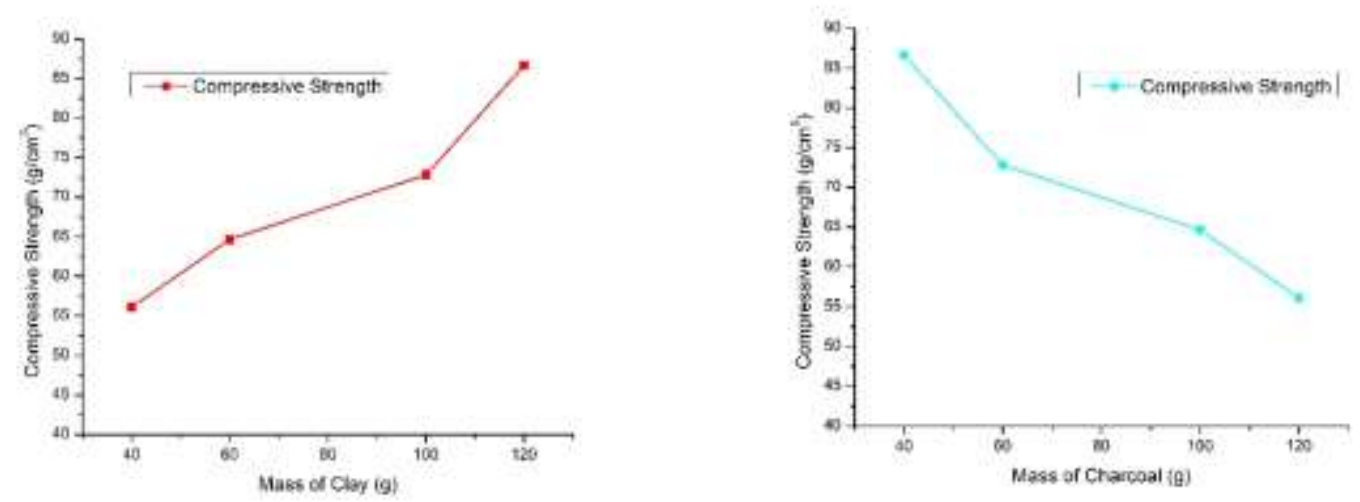

Figure 2. The relationship of compressive strength and mass of (a) Clay and (b) Charcoal 
Based on Figure 2a, the relationship of clay mass and compressive strength is directly proportional. This is based on the clay physical characteristic which was more solid when being heated [18]. On the other hand, the compressive strength values are inversely proportional to the charcoal mass. The increase of charcoal mass contained within the mixing composition of briquettes reduced the compressive strength (Figure 2b). Due to the charcoal is vulnerable to be fragile when being pressed, the charcoal contained in briquettes experienced expansion properties when it is dried within $85^{\circ} \mathrm{C}$ of temperature. From the Figure $2 \mathrm{~b}$, it obviously seen the decrease of compressive strength from sample $\mathrm{M}_{4}$ to $\mathrm{M}_{3}$ significantly due to the composition of charcoal is low compared to the $\mathrm{M}_{1}$ and $\mathrm{M}_{2}$.

\subsection{Specific heat value}

The charcoal and clay masses contained within the mixing composition affects the specific heat value. The heat values of charcoal are calculated by the equation 4 below [18-20]:

$$
Q_{b}=Q_{a}+Q_{g}+Q_{u}=m_{a} \cdot C_{a} \Delta T_{a}+M_{g} \cdot C_{g} \Delta T_{g}+M_{u} \cdot L_{u}
$$

where $Q_{b}$ is Specific heat value of charcoal, $Q_{a}$ is Water heat (cal), $Q_{g}$ is Glass heat (cal) and $Q_{u}$ is latent heat (cal).

The test results are illustrated by the following Table 3 .

Table 3. Specific Heat and Charcoal Mass

\begin{tabular}{ccccccc}
\hline Samples & $\begin{array}{c}\Delta \mathrm{Ta}\left({ }^{0} \mathrm{C}\right. \\
)\end{array}$ & $\Delta \mathrm{Tg}\left({ }^{0} \mathrm{C}\right)$ & $\mathrm{m}_{\mathrm{a}}($ gram $)$ & $\begin{array}{c}\text { Clay mass } \\
(\text { gram })\end{array}$ & $\begin{array}{c}\text { Charcoal } \\
\text { mass }(\text { gram })\end{array}$ & $\mathrm{Q}(\mathrm{Kcal} / \mathrm{kg})$ \\
\hline $\mathrm{M}_{1}$ & 73 & 69 & 19 & 50 & 150 & 246.68 \\
$\mathrm{M}_{2}$ & 73.5 & 70 & 18.6 & 100 & 125 & 209.38 \\
$\mathrm{M}_{3}$ & 73 & 70.4 & 18 & 125 & 100 & 176.48 \\
$\mathrm{M}_{4}$ & 73 & 71 & 17.5 & 150 & 50 & 162.26 \\
\hline
\end{tabular}

From the results of Table 3 above, it can be designed the line graph which shows the relationship of specific heat values $(\mathrm{Kcal} / \mathrm{kg}$ ) to the charcoal (Figure 3a), and the line graph displaying the relationship of specific heat values (Kcal/kg) to clay (Figure $3 \mathrm{~b}$ ).

The Figure 3a shows the specific heat values has declining trends with the charcoal mass of the briquettes composition, and this is caused by the high amounts of carbon elements within the charcoal. This also suggested the carbon is easily to be reacted as long as combustion is occurred. Based on the Figure 3b, the specific heat value is indirectly proportional to mass clay, which is caused by the higher solidity of the clay compared to the charcoal.

\subsection{Time ignitions measurement}

One of the aims of this research is how to fabricate briquettes that is easily to be ignited. One of the factors that can affect the ignition of briquettes is the ignited additive materials (rice husks 
ashes). The time ignition of briquettes samples are $\mathrm{M}_{1}=18.40 ; \mathrm{M}_{2}=18.70 ; \mathrm{M}_{3}=18.20 ; \mathrm{M}_{4}=$ 18.0 in a minute. Actually, the ignition time of $\mathrm{M}_{4}$ samples is the fastest due to the highest composition of ignited additives.
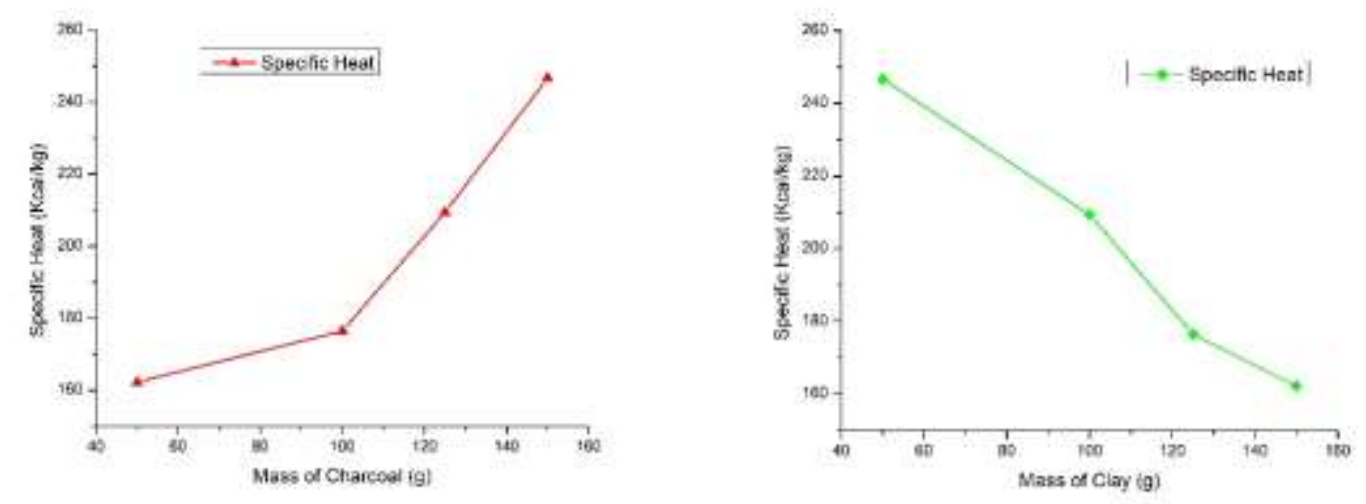

Figure 3. The relationship of specific heat and mass of (a) Charcoal and (b) Clay

\subsection{Ashes measurement}

To observe the formation of ashes after combustion, the briquettes were tested to determine the ashes, with the mixing of clay. The fabrication aims to produce briquettes with the un-scattered characteristics of ashes after combustion. In the ashes measurements, the amounts of mass loss are calculated by observing the pores formed according to the equations 3 . And this implies to the directly proportional to the mass loss of charcoal mass.

\section{Conclusions}

It can be concluded that the increase of charcoal composition provides higher specific heat, however the mass loss is increasing with fragile residual combustion material. In this study, the sample $\mathrm{M}_{1}$ has the highest specific heat accounted for $246.68 \mathrm{Kcal} / \mathrm{kg}$. The inclining clay compositions during the fabrication of charcoal briquettes produced lower specific heat values with 18 minutes of ignition time and hard residual combustion materials.

\section{References}

[1] G. Zhi, C. Peng, Y. Chen, D. Liu, G. Sheng and J. Fu, "Deployment of Coal Briquettes and Improved Stoves: Possibly An Option for Both Environment and Climate," Environmental Science and Technology, vol. 43, no. 15, pp. 5586-5591, 2009.

[2] N. Skoczylas, B. Dutka and J. Sobczyk, "Mechanical and Gaseous Properties of Coal Briquettes in Terms of Outburst Risk," Fuel, vol. 134, pp. 45-52, 2014.

[3] D. E. Clarke and H. Marsh, "Factors Influencing Properties of Coal Briquettes," Fuel, vol. 68, no. 8, pp. 1031-1038, 1989.

[4] "Ristek DIkti," [Online]. Available: http://www.ristek.go.id/file_upload/lain_lain/ 
briket_batubara_1.html. [Accessed 15 December 2011].

[5] D. Vamvuka, "Bio-oil, Solid and Gaseous Biofuels from Biomass Pyrolysis Processes - An Overview," International Journal of Energy Research, vol. 35, no. 10, pp. 835-862, 2011.

[6] A. Mohammad-Khah and R. Ansari, "Activated Charcoal: Preparation, Characterization and Applications: A Review Article," International Journal of ChemTech Research, vol. 1, no. 4, pp. 859-864, 2009.

[7] J. Bourke, M. M. Harris, C. Fushimi, K. Dowaki, T. Nunoura and M. J. Antal, "Do All Carbonized Charcoals Have The Same Chemical Structure? 2. A Model of The Chemical Structure of Carbonized Charcoal," Industrial \& Engineering Chemistry Research, vol. 46, no. 18, pp. 5954-5967, 2007.

[8] D. Y. Sukarna, Coal Technology Research and Development for Metalurgi, Serpong: LIPI, 1988.

[9] Q. Zhong, Y. Yang, Q. Li, B. Xu and T. Jiang, "Coal Tar Pitch and Molasses Blended Binder for Production of Formed Coal Briquettes from High Volatile Coal," Fuel, Processing Technology, vol. 157, pp. 12-19, 2017.

[10] J. T. Oladeji, "Theoretical Aspects of Biomass Briquetting: A Review Study," Journal of Energy Technologies and Policy, vol. 5, no. 3, pp. 72-81, 2015.

[11] W. E. Woral, Clays and Ceramics Raw Materials Edisi Kedua, London: Elsevier Applied Science Publisher, 1986.

[12] J. Kaoma, G. B. Kasali and A. Ellegard, Efficiency and Emissions of Charcoal Use in The Improved Mbaula Cookstove, Sweden: Stockholm Environment Institute, 1994.

[13] D. J. Dell, "Charcoal Briquettes Bound With An Organic Binder and A Water-Swellable Clay and Method," U.S. Patent 5221290A, June 22, 1993.

[14] L. Shao, C. Hou, C. Geng, J. Liu, Y. Hu, J. Wang, T. Jones, C. Zhao and K. BéruBé, "The Oxidative Potential of $\mathrm{PM}_{10}$ from Coal, Briquettes and Wood Charcoal Burnt in An Experimental Domestic Stove," Atmospheric Environment, vol. 127, pp. 372-381, 2016.

[15] P. C. W. Kwong, C. H. Y. Chao, J. H. Wang, C. W. Cheung and G. Kendall, "Cocombustion Performance of Coal With Rice Husks and Bamboo," Atmospheric Environment, vol. 41, no. 35, pp. 7462-7472, 2007.

[16] W. Permchart and V. I. Kouprianov, "Emission Performance and Combustion Efficiency of A Conical Fluidized-Bed Combustor Firing Various Biomass Fuels," Bioresource Technology, vol. 92, no. 1, pp. 83-91, 2004.

[17] R. Blissett, R. Sommerville, N. Rowson, J. Jones and B. Laughlin, "Valorisation of Rice Husks Using A TORBED® Combustion Process," Fuel Processing Technology, vol. 159, pp. 247-255, 2017.

[18] M. J. Djokosetyardjo, Ketel Uap, Jakarta: Pradnya Paramita, 1993.

[19] F. Kreith and S. B. Mark, Principles of Heat Transfer Edisi Keempat, New York: Harper \& Raw Publisher, 1986.

[20] M. W. Zemansky and H. D. Richard, Dittman.Kalor dan Termodinamika Edisi Keenam Terjemahan, Bandung: ITB, 1986. 